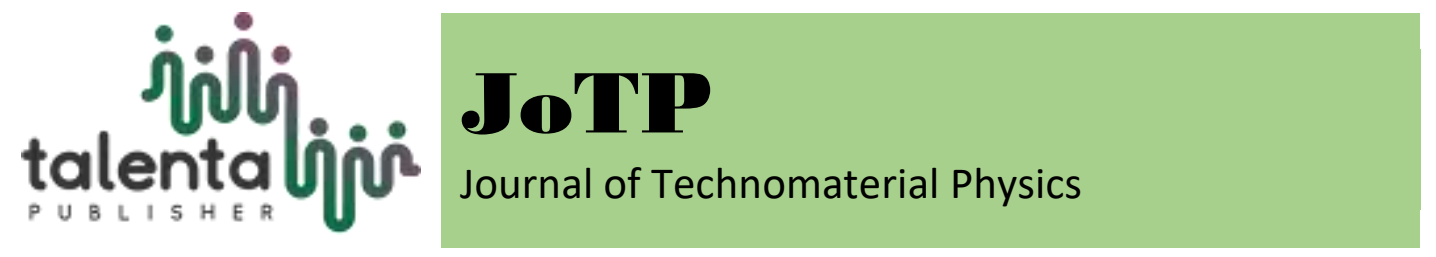

\title{
Analysis of Cassava Peel Paste as an Electrolyte of Electrical Energy Source
}

\author{
Amir Supriyanto ${ }^{1}$, Arif Surtono ${ }^{2}$ and Tri Sutanto ${ }^{3}$ \\ 1,2,3 Department of Physics, Faculty of Mathematics and Natural Science, Universitas Lampung 35145, Indonesia.
}

\begin{abstract}
The electrical characteristics of cassava peel can be detected by using a pair of electrodes, $\mathrm{Cu}$ and $\mathrm{Zn}$. Measurement of electrical characteristics is done when the cassava peel is given a 5 watt LED load and when the load is removed. Cassava peel are used in two different ways: fermented and non-fermented. The electrolyte cell used consisted of 20 cells, assembled in three different types: 20 series, 10 series with 2 parallel, and 5 series with 4 parallel. The volume of each cell's paste is $200 \mathrm{ml}$. The measurement results show that the 20 series circuit produces the greatest electrical voltage, but the electric current is small and the resistance is large. While the series with 20 cells and 5 series with 4 parallel obtained maximum power. The cassava peel which were fermented for 72 hours can increase the electrical power generated from the three types of circuits.
\end{abstract}

Keyword: electricity, fermentation, cassava peel

Received 5 December 2018 | Revised [21 February 2019] | Accepted [28 February 2019]

\section{Introduction}

Electrical energy source is a basic human need that continues to increase. The limited conventional electric energy sources require us to find a variety of alternative energy sources that are safe and environmentally friendly. One of the abundant natural resources in Indonesia and potentially as a source of electrical energy is cassava peel waste. Cassava peel contains as much as $16.72 \%$ carbohydrates which can form acetic acid $\left(\mathrm{CH}_{3} \mathrm{COOH}\right)$ and cyanide acid $(\mathrm{HCN})$. The acid solution is one of the electrolytes that can generate electric current, so it is very possible that cassava peel can produce electric current. To find out the electrical characteristics of cassava peel two electrodes are going to be used, namely zinc ( $\mathrm{Zn})$ and copper $(\mathrm{Cu})$.

One way to produce electrical energy sources is by electrochemical reactions. Electrochemical reactions can occur through two electrodes with a potential difference and are in the electrolyte [1]. The electrical energy generated depends on the type of electrolyte solution and the

\footnotetext{
*Corresponding author at: J1.Prof. Dr. Soemantri Brojonegoro No.1 Gedung Meneng Bandar Lampung 35145

E-mail address: amirsupriyanto65@gmail.com
} 
electrode. It also depends on the type of material and the modification of the electrode's dimensions.

Research to determine the electrical effects caused by variations in electrode materials using electrolytes in addition to chemical solutions has been carried out [2-7]. Utilized citrus fruit waste as an electrolyte, which were carried out by utilizing used batteries with banana peel waste and durian as an alternative energy source. Banana peels contains carbohydrates that can form ethanol. Afterwards, ethanol will be oxidized to ethanoic acid or acetic acid. Acetic acid is one type of electrolyte [8-13] performed a different variation on the fermentation time which uses banana peel solution as an accu cell electrolyte solution. The longer the fermentation time, the more acidic the material becomes which is indicated by the decreasing $\mathrm{pH}$ value. The decrease in $\mathrm{pH}$ value is caused by the increasing activity of microorganisms in the material, which causes organic compounds to oxidize and turns into carbon dioxide by directly transferring electrons [14-17] conducted an electrical characteristics analysis using various types of cassava and cassava peels in the form of solution so that it could be used to charge cellphone batteries. The analysis that has been carried out shows that cassava skin is capable of producing electrical power from $\mathrm{Cu}-\mathrm{Zn}$ electrodes and is able to turn on 1.2 watts of LED. During the test, a cellphone battery was charged. However, it did not increase the cellphone's life time by long period of time because the current was small. Therefore, it is necessary to do further research to get a greater current and power that is by giving fermented cassava skin treatment and changing the cell circuit from the series into parallel electricity, fermentation, cassava peel.

\section{Materials and Methods}

The research consisted of two steps, namely designing and creating the test media of cassava peel's electrical characteristics, then testing the electricity characteristic of the cassava peel. The chamber is made of acrylic material which is turned into a box to accommodate cassava peel. The box length was $10 \mathrm{~cm}$, with width of $6 \mathrm{~cm}$ wide, and height of $7 \mathrm{~cm}$. After that, a pair of electrodes $(\mathrm{Cu}-\mathrm{Zn})$ was assembled with a height of $8 \mathrm{~cm}$ and a width of $5 \mathrm{~cm}$, each cell will be inserted to $200 \mathrm{ml}$ cassava or cassava peel paste. Then, the cell containing the pair of electrodes is arranged in series of up to 20 cells. The media design for testing the electrical characteristics of cassava peel in this study can be seen in Figure 1. Cassava and cassava peel was cleaned and then was processed into paste by using a blender with a little water. Afterwards, cassava peel paste is put into the media tests that were previously made, then it was tested by giving a 5 watt LED circuit load for 24 hours then it was measured every 2 hours. There were two different types of cassava peels which were used, first is without fermentation and second is cassava peels with 72 hours fermentation. The test is carried out by measuring the electrical characteristics of cassava peel when the load is removed $\left(\mathrm{V}_{\mathrm{bl}}\right)$, when using the load $\left(\mathrm{V}_{\mathrm{b}}\right)$ and the current (I) produced, as shown in Figure 2. 


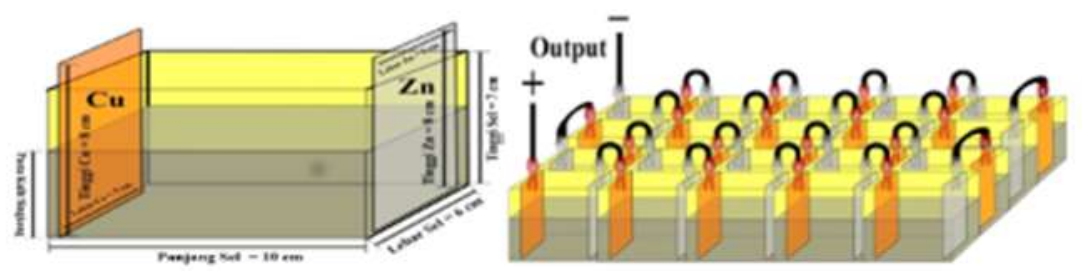

(a).

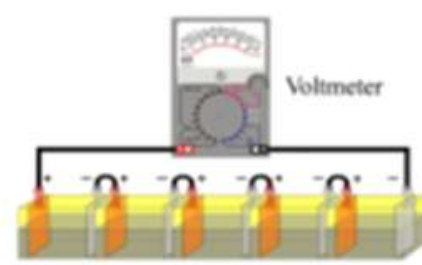

(b)

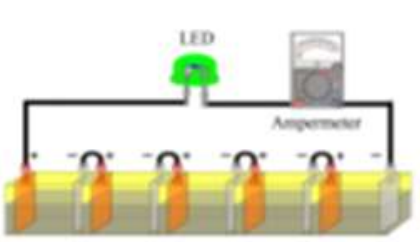

(c)

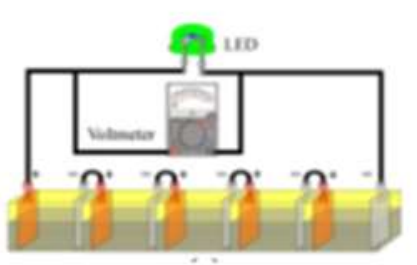

(d)

Figure 1. (a) Media design of the test site, (b) Measuring the voltage at load removed $\left(\mathrm{V}_{\mathrm{bl}}\right)$, (c) Current Measurement (I), (d) Current voltage measurement use load $\left(\mathrm{V}_{\mathrm{b}}\right)$

Data collection was carried out by using 20 cells arranged in 20 series, 10 series with 2 parallel, and 5 series with 4 parallel. Before retrieving the data on electrical characteristics, it will also retrieve the authentic data by using a $\mathrm{pH}$ meter.

\section{Result and Discussion}

The first electrical characteristics testing of the cassava peel is the testing of the electrical characteristics of the voltage when released and $\mathrm{V}_{\mathrm{bl}}$ and with the load $\left(\mathrm{V}_{\mathrm{b}}\right)$, and the electric current strength (I) using the $\mathrm{Cu}-\mathrm{Zn}$ electrode. The results of testing the electrical characteristics of cassava peel are presented in Table 1 up to Table 6.

Table 1. Electrical characteristics of fermented cassava peel of 20 cell series

\begin{tabular}{cccccc}
\hline $\begin{array}{c}\text { Time } \\
(\text { Hour })\end{array}$ & $\begin{array}{c}\mathrm{V}_{\mathrm{bl}} \\
(\text { Volt })\end{array}$ & $\begin{array}{c}\mathrm{V}_{\mathrm{b}} \\
(\text { Volt })\end{array}$ & $\begin{array}{c}\mathrm{I} \\
(\mathrm{mA})\end{array}$ & $\begin{array}{c}\mathrm{P} \\
(\mathrm{mW})\end{array}$ & $\begin{array}{c}\mathrm{R}_{\mathrm{in}} \\
(\mathrm{k} \Omega)\end{array}$ \\
\hline 0 & 12.27 & 7.42 & 0.28 & 2.07 & 17.32 \\
2 & 10.82 & 7.38 & 0.23 & 1.69 & 14.96 \\
4 & 10.51 & 7.36 & 0.21 & 1.54 & 15.00 \\
6 & 10.34 & 7.35 & 0.19 & 1.39 & 15.73 \\
8 & 10.27 & 7.33 & 0.18 & 1.32 & 16.33 \\
10 & 10.19 & 7.31 & 0.17 & 1.24 & 16.94 \\
12 & 10.11 & 7.29 & 0.16 & 1.16 & 17.62 \\
14 & 10.04 & 7.27 & 0.14 & 1.02 & 19.78 \\
16 & 10.09 & 7.30 & 0.15 & 1.09 & 18.60 \\
18 & 10.14 & 7.32 & 0.16 & 1.17 & 17.62 \\
20 & 10.02 & 7.33 & 0.17 & 1.25 & 15.82 \\
22 & 9.89 & 7.31 & 0.17 & 1.24 & 15.18 \\
24 & 9.47 & 7.30 & 0.16 & 1.17 & 13.56 \\
\hline
\end{tabular}


Table 2. Electrical characteristics of fermented cassava peel of 20 cell series

\begin{tabular}{cccccc}
\hline $\begin{array}{c}\text { Time } \\
(\text { Hour })\end{array}$ & $\begin{array}{c}\mathrm{V}_{\mathrm{bl}} \\
(\text { Volt })\end{array}$ & $\begin{array}{c}\mathrm{V}_{\mathrm{b}} \\
(\text { Volt })\end{array}$ & $\begin{array}{c}\mathrm{I} \\
(\mathrm{mA})\end{array}$ & $\begin{array}{c}\mathrm{P} \\
(\mathrm{mW})\end{array}$ & $\begin{array}{c}\mathrm{R}_{\text {in }} \\
(\mathrm{k} \Omega)\end{array}$ \\
\hline 0 & 10.90 & 7.50 & 0.62 & 4.65 & 5.48 \\
2 & 10.53 & 7.46 & 0.51 & 3.80 & 6.02 \\
4 & 10.47 & 7.44 & 0.48 & 3.57 & 6.31 \\
6 & 10.34 & 7.41 & 0.44 & 3.26 & 6.65 \\
8 & 10.23 & 7.40 & 0.38 & 2.81 & 7.45 \\
10 & 10.08 & 7.40 & 0.31 & 2.29 & 8.64 \\
12 & 10.01 & 7.39 & 0.27 & 1.99 & 9.70 \\
14 & 9.89 & 7.38 & 0.23 & 1.69 & 10.91 \\
16 & 9.68 & 7.36 & 0.19 & 1.39 & 12.21 \\
18 & 9.44 & 7.35 & 0.21 & 1.54 & 9.95 \\
20 & 9.34 & 7.34 & 0.19 & 1.39 & 10.52 \\
22 & 9.21 & 7.33 & 0.18 & 1.32 & 10.44 \\
24 & 9.13 & 7.32 & 0.17 & 1.24 & 10.65 \\
\hline
\end{tabular}

Table 3. Electrical characteristics of cassava peel without fermentation with 20 cells, arranged in 10 series and then paralleled in 2

\begin{tabular}{cccccc}
\hline $\begin{array}{c}\text { Time } \\
\text { (Hour) }\end{array}$ & $\begin{array}{c}\mathrm{V}_{\mathrm{bl}} \\
(\text { Volt })\end{array}$ & $\begin{array}{c}\mathrm{V}_{\mathrm{b}} \\
(\text { Volt })\end{array}$ & $\begin{array}{c}\mathrm{I} \\
(\mathrm{mA})\end{array}$ & $\begin{array}{c}\mathrm{P} \\
(\mathrm{mW})\end{array}$ & $\begin{array}{c}\mathrm{R}_{\text {in }} \\
(\mathrm{k} \Omega)\end{array}$ \\
\hline 0 & 6.15 & 3.75 & 0.58 & 2.17 & 4.14 \\
2 & 5.46 & 3.68 & 0.48 & 1.76 & 3.71 \\
4 & 5.27 & 3.63 & 0.43 & 1.56 & 3.81 \\
6 & 5.19 & 3.62 & 0.39 & 1.41 & 4.02 \\
8 & 5.14 & 3.61 & 0.37 & 1.33 & 4.14 \\
10 & 5.09 & 3.60 & 0.35 & 1.26 & 4.26 \\
12 & 5.06 & 3.60 & 0.33 & 1.18 & 4.42 \\
14 & 5.03 & 3.61 & 0.29 & 1.05 & 4.89 \\
16 & 5.04 & 3.61 & 0.31 & 1.12 & 4.61 \\
18 & 5.05 & 3.62 & 0.32 & 1.16 & 4.47 \\
20 & 5.04 & 3.61 & 0.33 & 1.19 & 4.33 \\
22 & 5.02 & 3.61 & 0.34 & 1.23 & 4.15 \\
24 & 4.96 & 3.60 & 0.33 & 1.19 & 4.12 \\
\hline
\end{tabular}

Table 4. Electrical characteristics of cassava peel fermented with 20 cells, arranged in 10 series and then paralleled in 2

\begin{tabular}{cccccc}
\hline $\begin{array}{c}\text { Time } \\
\text { (Hour) }\end{array}$ & $\begin{array}{c}\mathrm{V}_{\mathrm{bl}} \\
(\text { Volt })\end{array}$ & $\begin{array}{c}\mathrm{V}_{\mathrm{b}} \\
(\text { Volt })\end{array}$ & $\begin{array}{c}\mathrm{I} \\
(\mathrm{mA})\end{array}$ & $\begin{array}{c}\mathrm{P} \\
(\mathrm{mW})\end{array}$ & $\begin{array}{c}\mathrm{R}_{\mathrm{in}} \\
(\mathrm{k} \Omega)\end{array}$ \\
\hline 0 & 5.47 & 3.77 & 1.18 & 4.44 & 1.44 \\
2 & 5.32 & 3.74 & 1.02 & 3.81 & 1.55 \\
4 & 5.27 & 3.72 & 0.83 & 3.09 & 1.87 \\
6 & 5.23 & 3.71 & 0.71 & 2.63 & 2.14 \\
8 & 5.19 & 3.70 & 0.63 & 2.33 & 2.36 \\
10 & 5.14 & 3.70 & 0.56 & 2.07 & 2.57 \\
12 & 5.08 & 3.70 & 0.49 & 1.81 & 2.82 \\
14 & 5.01 & 3.69 & 0.43 & 1.59 & 3.07 \\
16 & 4.93 & 3.68 & 0.39 & 1.43 & 3.20 \\
18 & 4.85 & 3.68 & 0.37 & 1.36 & 3.16 \\
20 & 4.78 & 3.68 & 0.35 & 1.29 & 3.14 \\
22 & 4.65 & 3.68 & 0.32 & 1.18 & 3.03 \\
24 & 4.54 & 3.67 & 0.30 & 1.10 & 2.90 \\
\hline
\end{tabular}


Table 5. Electrical characteristics of cassava peel without fermentation with 20 cells, arranged in 5 series then paralleled in 4

\begin{tabular}{cccccc}
\hline $\begin{array}{c}\text { Time } \\
\text { (Hour) }\end{array}$ & $\begin{array}{c}\mathrm{V}_{\mathrm{bl}} \\
(\text { Volt })\end{array}$ & $\begin{array}{c}\mathrm{V}_{\mathrm{b}} \\
(\text { Volt })\end{array}$ & $\begin{array}{c}\mathrm{I} \\
(\mathrm{mA})\end{array}$ & $\begin{array}{c}\mathrm{P} \\
(\mathrm{mW})\end{array}$ & $\begin{array}{c}\mathrm{R}_{\text {in }} \\
(\mathrm{k} \Omega)\end{array}$ \\
\hline 0 & 3.07 & 1.86 & 1.07 & 1.99 & 1.13 \\
2 & 2.72 & 1.85 & 0.93 & 1.72 & 0.94 \\
4 & 2.68 & 1.84 & 0.82 & 1.51 & 1.02 \\
6 & 2.67 & 1.84 & 0.74 & 1.36 & 1.12 \\
8 & 2.65 & 1.83 & 0.65 & 1.19 & 1.26 \\
10 & 2.62 & 1.82 & 0.59 & 1.07 & 1.36 \\
12 & 2.58 & 1.82 & 0.55 & 1.00 & 1.38 \\
14 & 2.54 & 1.81 & 0.53 & 0.96 & 1.38 \\
16 & 2.56 & 1.81 & 0.57 & 1.03 & 1.32 \\
18 & 2.59 & 1.82 & 0.62 & 1.13 & 1.24 \\
20 & 2.55 & 1.83 & 0.65 & 1.19 & 1.11 \\
22 & 2.49 & 1.82 & 0.63 & 1.15 & 1.06 \\
24 & 2.37 & 1.81 & 0.61 & 1.10 & 0.92 \\
\hline
\end{tabular}

Table 6. Electrical characteristics of cassava skin fermented with 20 cells, arranged in 5 series and then paralleled 4

\begin{tabular}{cccccc}
\hline $\begin{array}{c}\text { Time } \\
\text { (Hour })\end{array}$ & $\begin{array}{c}\mathrm{V}_{\mathrm{bl}} \\
(\text { Volt })\end{array}$ & $\begin{array}{c}\mathrm{V}_{\mathrm{b}} \\
(\text { Volt })\end{array}$ & $\begin{array}{c}\mathrm{I} \\
(\mathrm{mA})\end{array}$ & $\begin{array}{c}\mathrm{P} \\
(\mathrm{mW})\end{array}$ & $\begin{array}{c}\mathrm{R}_{\text {in }} \\
(\mathrm{k} \Omega)\end{array}$ \\
\hline 0 & 2.75 & 1.88 & 2.43 & 4.57 & 0.36 \\
2 & 2.64 & 1.86 & 2.02 & 3.76 & 0.37 \\
4 & 2.62 & 1.85 & 1.88 & 3.48 & 0.41 \\
6 & 2.59 & 1.85 & 1.72 & 3.18 & 0.43 \\
8 & 2.56 & 1.85 & 1.45 & 2.68 & 0.49 \\
10 & 2.53 & 1.85 & 1.18 & 2.18 & 0.58 \\
12 & 2.51 & 1.85 & 1.02 & 1.89 & 0.65 \\
14 & 2.48 & 1.84 & 0.90 & 1.65 & 0.71 \\
16 & 2.44 & 1.84 & 0.84 & 1.54 & 0.71 \\
18 & 2.41 & 1.84 & 0.81 & 1.49 & 0.70 \\
20 & 2.38 & 1.84 & 0.75 & 1.38 & 0.72 \\
22 & 2.35 & 1.84 & 0.69 & 1.27 & 0.74 \\
24 & 2.31 & 1.83 & 0.63 & 1.15 & 0.60 \\
\hline
\end{tabular}

Based on the potential value reduction of the voltaic series shows that copper has a potential difference of $+0.34 \mathrm{~V}$, while zinc has a potential difference of $-0.76 \mathrm{~V}$. Therefore, the potential difference resulting from the second series of electrodes is $1.10 \mathrm{~V}$. Meanwhile, the results of the study yielded an average maximum electric potential value of one cell in the no-load cassava peel of $0.61 \mathrm{~V}$.

The test when cells are arranged in series resulted in a no-load voltage $\left(\mathrm{V}_{\mathrm{bl}}\right)$ and a voltage with load $\left(\mathrm{V}_{\mathrm{bl}}\right)$ is greater than the one in parallel. This is consistent with research related to the use of electrolyte biomass as a battery [18-20] which shows that the increasing amount of biomass electrolyte cells can increase the voltage electrical characteristics.

The second test is a test on electrical characteristics of cassava peel when given a load $\left(\mathrm{V}_{\mathrm{b}}\right)$. The load used in this test is a LED with a large 5 watt load. The results of testing the electrical 
characteristics when using a load $\left(\mathrm{V}_{\mathrm{b}}\right)$ shows that although the voltage decreased but it is quite stable for 24 hours. Testing the electrical characteristics of the electric current (I) when using the load; it appears that as long as the LED lights up the electric current, it will decrease with duration of usage. The decrease in current generated during the test occurs because the electrolyte used has decreased ionization, which means that the ions in the electrolyte have not been able to maximally deliver electric current. This indicates that cassava peel naturally undergoes a decomposition process of the ions contained. Measured electrical power based on voltage and current characteristics, cassava peel electrolytes that have been fermented for 72 hours is greater than without fermentation. The biggest electric power for non-fermented cassava peel electrolyte with 20 cell series is $2.07 \mathrm{~mW}$, arranged in 10 series then paralleled in 2: $2.17 \mathrm{~mW}$, and assembled in 5 series then paralleled in 4: $1.99 \mathrm{~mW}$. While, the electrolytic power of fermented cassava peel arranged in 20 cell series: $4.65 \mathrm{~mW}$, strung in 10 series then paralleled in 2: $4.44 \mathrm{~mW}$, and assembled in 5 series then paralleled 4: $4.57 \mathrm{~mW}$. This is consistent with the research of Hendri et al [8] which stated the longer the fermentation time, the more acidic the material gets. The increase in electrolyte acidity was shown by the decrease of electrolyte $\mathrm{pH}$ of non-fermented cassava peel 6.7 and after fermentation 4.6.

Afterwards, the electrical characteristics of the barriers $\left(R_{\text {in }}\right)$ in cassava peel was tested. The $R_{\text {in }}$ achieved from the test the result of a reduction between the voltage when the load is released and the voltage using the load then divided by the current. The electrical characteristics of the internal resistance $\left(\mathrm{R}_{\text {in }}\right)$ will increase along with a huge decrease in the electrical current produced. The resistance in the resulting series of fermented cassava peel electrolytes is smaller than without fermentation. The smallest resistance $\left(R_{i n}\right)$ for non-fermented cassava peel electrolyte are as follows, 20 cell series configuration: $13.562 \mathrm{k} \Omega$, assembled in 10 series then paralleled in 2: $1.44 \mathrm{k} \Omega$, and assembled in 5 series then paralleled in 4: $0.92 \mathrm{k} \Omega$. Whereas, the least resistance in $\left(\mathrm{R}_{\mathrm{in}}\right)$ of electrolytic fermented cassava peel are as follows, assembled with 20 cells of series: $5.48 \mathrm{k} \Omega$, assembled together in 10 series and then paralleled in $2: 1.44 \mathrm{k} \Omega$, and assembled in 5 series then paralleled in $4: 0.36 \mathrm{k} \Omega$.

\section{Conclusion}

Based on the results of the research and analysis that has been carried out, it can be concluded that cassava peel paste is able to produce electrical power using $\mathrm{Cu}-\mathrm{Zn}$ electrodes and is able to turn on 5 watts of LED. In order to increase current and electric power also at the same time reduce internal resistance, cell circuits can be made in series and parallel modification. Fermented cassava peel paste can increase the electrical power produced. Deep barriers in cassava peel cells are large enough so that further research is needed to overcome the deep barriers in cassava peel cells which can ultimately increase the electric current. 
The author would like to thank the Head of the Laboratory of the Physics Department of the University of Lampung for providing the laboratory facilities.

\section{REFERENCES}

[1] J. E. Brady, Kimia Universitas Asas dan Struktur Jilid 1, Tanggerang: Binarupa Aksara Publisher, 2010.

[2] J. Muhlisin, M. N. Soedjarwanto and M. Komarudin, "Pemanfaatan Sampah Kulit Pisang dan Kulit Durian Sebagai Bahan Alternatif Pengganti Pasta Batu Baterai.Electrician," Jurnal Rekayasa dan Teknologi Elektro, vol. 11, no. 3, p. 137-147, 2017.

[3] H. Petrucci, Rapih and Suminar, Kimia Dasar Prinsip dan Terapan Modern, Jilid 2, Jakarta: Erlangga, 1987.

[4] T. Linsley, Instalasi Listrik Dasar, W. S. Wibi Hardani, Ed., Jakarta: Erlangga, 2004.

[5] E. H. Landis, "Some of the Laws Concersing Voltaic Cells.," The Journal of the Franklin Institute of the State of Pennsylvania, vol. CLXVIII, no. 6, pp. 399-420, 1909.

[6] Lisdawati, A. Novia and M. Faridha, "Pengaruh Variasi Suhu dan Waktu Pengeringan Sampel Pasta Baterai Kulit Pisang Kepok "Manurun" pada Tegangan dan Arus Listrik Baterai," Jurnal EEICT (Electric, Electronic, Instrumentation, Control, Telecommunication, vol. 1, no. 1, 2018.

[7] Widyaningsih, W. Purwati and T. H. Mulud, "Analisis Pemanfaatan Limbah Kulit Pisang Sebagai Energi Alternatif Pada Batterai," Eksergi, vol. 13, no. 2, 2017.

[8] Hendri, Yasni, Gusnedi and Ratnawulan, "Pengaruh jenis kulit pisang dan variasi waktu fermentasi. terhadap kelistrikan dari sel ACCU Dengan menggunakan larutan kulit pisang," Pillar of Physics, vol. 6, pp. 97-104, 2015.

[9] Lotfabad, E. Memarzadeh and et al, "High-density sodium and lithium ion battery anodes from banana peels," ACS nano, vol. 8, no. 7, pp. 7115-7129, 2014.

[10] Y. Zhang and et al, "High-performance supercapacitors and batteries derived from activated banana-peel with porous structures," Electrochimica Acta, vol. 222, pp. 12571266, 2016.

[11] J. Xiang and et al, "Activated hard carbon from orange peel for lithium/sodium ion battery anode with long cycle life," Journal of Alloys and Compounds, vol. 701, pp. 870-874, 2017.

[12] Y. Li and et al, "Tire-derived carbon composite anodes for sodium-ion batteries," Journal of Power Sources, vol. 316, pp. 232-238, 2016.

[13] R. R. Gaddam and et al, "Biomass derived carbon nanoparticle as anodes for high performance sodium and lithium ion batteries," Nano Energy, vol. 26, pp. 346-352, 2016.

[14] Irsan, A. Supriyanto and A. Surtono, "Analisis Karakteristik Limbah Kulit Singkong (Manihot Esculenta Crantz) Sebagai Sumber Energi Listrik Alternatif Terbarukan Untuk Mengisi Baterai Handphone," Jurnal Teori dan Aplikasi Fisika, vol. 5, no. 1, pp. 9-18, 2016.

[15] T. Susanto, "ANALISIS KARAKTERISTIK ELEKTRIK LIMBAH KULIT SINGKONG BERBENTUK PASTA SEBAGAI SUMBER ENERGI LISTRIK ALTERNATIF TERBARUKAN," Skripsi, 2018.

[16] S. Imtiaz and et al, "Biomass-derived nanostructured porous carbons for lithium-sulfur batteries," Science China Materials, vol. 59, no. 5, pp. 389-407, 2016.

[17] A. M. Abioye and F. N. Ani, "Recent development in the production of activated carbon electrodes from agricultural waste biomass for supercapacitors: a review," Renewable and sustainable energy reviews, vol. 52, pp. 1282-1293, 2015.

[18] K. Sudhakar, R. Ananthakrishnan, A. Goyal and H. K. Darji, "A Novel Design ofMultiChambered Biomass Battery," International Journal of Renewable Energy Development 
(IJRED), vol. 2, no. 1, pp. 31-34, 2013.

[19] A. D. Dalvi, N. Mohandas, O. A. Shinde and T. P. Kininge, "Microbial fuel Cell for Production of Bioelectricity from Waste and Biological Waste Treatment," IJABR, vol. 2, no. 2, pp. 263-268, 2011.

[20] N. Mano, F. Mao and A. Heller, "Characteristics of a miniature compartment-less glucoseO2 biofuel cell and its operation in a living plant," J. Am. Chem. Soc., vol. 125, no. 21, p. 6588-6594, 2003. 